\title{
Microbiological Treatment of Effluent for Zinc Hydrometallurgical Plant
}

\author{
Ashish Kumar , Krishna Deo Sharma and Sunil Duggal \\ Central R\&D Laboratory, Hindustan Zinc Limited, Udaipur 313024, India
}

Received: December 20, 2013 / Accepted: January 07, 2014 / Published: April 25, 2014.

\begin{abstract}
Sulfate reducing bacteria were isolated from the soil sample of Roaster-Acid unit of Debari Zinc Smelter of Hindustan Zinc Ltd., India and were adapted for effluent water of Zinc hydrometallurgy plant to sustain zinc concentration of about 500 ppm and iron concentration of about $160 \mathrm{ppm}$ with high acidity $(\mathrm{pH}<1.0)$. Nutrient broth, whey, ethanol and sucrose were tested as carbon source for SRB (sulfate reducing bacteria) out of which whey was found as the best electron donor to expedite the rate of biological treatment with SRB. A two stage anaerobic bioreactor was developed with a treatment capacity of $30 \mathrm{~L}$ effluent water in 4 days. The concentration of heavy metals in the treated water was within the permissible limits. The suggested methodology generates no solid waste, is environment friendly and may be commercially implemented for treatment of zinc plant effluent.
\end{abstract}

Key words: Sulfate reducing bacteria, anaerobic treatment, isolation, hydrometallurgy effluent.

\section{Introduction}

Industrial wastewaters especially originating from acid mine drainage and hydrometallurgical industries contain high concentration of heavy metals as sulfates with free acidity. The improper treatment and/or discharge of this acidic water can have serious environmental impacts and can unbalance sulfur cycle [1]. Conventionally, the effluent water is being neutralized with lime followed by alum flocculation. The method is expensive and results in high total dissolved solids in treated water along with generation of residual sludge, which is dumped in SLF (secured land fill) sites and needs a large capital expenditure resulting in permanent loss of fertility of costly land. Membrane separation is also being used as an alternative route in effluent treatment to reduce solid waste load. However, relatively high cost of frequent membrane replacement and energy consumption restricts commercial use of this technique [2]. Recently, biotechnology has shown new opportunities and

\footnotetext{
*Corresponding author: Ashish Kumar, Manager (Technology Development), research field: non-ferrous metallurgy. Email: ashish.be@gmail.com.
}

challenges in many sectors especially in environmental remediation of industrial wastes (solid/liquid) to achieve better environment management and pollution control.

Present research is conducted with an aim of in-situ precipitation of heavy metals as metal sulfides from effluent of zinc hydrometallurgical plant. The advantage of sulfide precipitation include: better water quality due to lower solubility of metal sulfides compared with their corresponding hydroxides; selective precipitation of high grade metal sulfide concentrates that can be reprocessed to earn revenue; reduction in sludge volume; and toxicity and opportunities in reagent saving. A better overall environment solution can be attained due to metal recycle and effective solid-liquid separation. Under anaerobic conditions, SRB (sulfate-reducing bacteria) oxidize simple organic compounds completely to $\mathrm{CO}_{2}$ by utilizing sulfates as electron acceptor and generate sulfides and alkalinity [3]. SRB utilize a number of volatile fatty acids and hydrogen as electron donors to expedite its activity [4]. These sulfides subsequently precipitate metals as metal sulfides in in-situ 
conditions with saving of costly reagents like lime and sodium sulfide. Metal sulfides can also be precipitated using biogenic $\mathrm{H}_{2} \mathrm{~S}$ in ex-situ conditions [5, 6]. Hybrid $\mathrm{H}_{2} \mathrm{~S}$ bioreactor concept has also been introduced by controlling methanogenic reactions of typical anaerobic sludge reactor [7]. In case of anaerobic bacteria, sulfates are the main source of $\mathrm{H}_{2} \mathrm{~S}$ production and its concentration results in major impact on SRB growth [8]. SRB consumes approximately one to two moles of protons per mole of sulfate that is reduced and produces approximately two equivalents of alkalinity per mole of reduced sulfate [9]. The electron accounting can be made by assuming complete oxidation of organic compounds [5]. SRB are notable for their end product, hydrogen sulfide, which is far more noticeable substance than sulfates due to its chemical properties and physiological effects [10]. SRB could be carbon limited in organic medium containing cow manure and saw dust since these materials are largely polymers of cellulose and hemicellulose, which are insoluble organic matters [11, 12].

This paper includes isolation, screening and adaptation of SRB from hydrometallurgical smelter of Hindustan Zinc Limited at Udaipur in India. Evaluation of culture performance on bioreactor of $30 \mathrm{~L}$ effluent treatment capacity has also been analyzed and discussed.

\section{Experimental Materials and Methods}

\subsection{Effluent Water}

Effluent water from DZS (Debari Zinc Smelter) was collected in sealed poly vinyl containers and the heavy metals were analyzed by Atomic Absorption Spectrophotometer (Varian 220), while acidity and sulfates were analyzed by conventional titrimetry and gravimetric methods. The analysis of untreated (collected from DZS) and treated effluent (anaerobic bioreactor) is shown in Table 1.

\subsection{Isolation and Selection of SRB}

To isolate SRB, soil samples were collected from different locations of DZS of Hindustan Zinc Ltd. The locations were: roaster, acid plant, effluent plant, oxidation pond, cow dung sample and concentrate storage yard. The samples were serially diluted for $10^{-10}$ dilutions with proper mixing and poured in Petridishes filled with Postgate media [13] using agar as solidifying medium. The sterile conditions were maintained throughout the activities. Petridishes were incubated under anaerobic conditions at $30{ }^{\circ} \mathrm{C}$ for $48 \mathrm{~h}$. The anaerobic conditions in the chamber were maintained by creating vacuum and filling it with $\mathrm{N}_{2}$ gas. The sterility inside incubation chamber was maintained by cleaning the chamber with ethanol and further $\mathrm{N}_{2}$ gas was passed through air filter.

Table 1 Chemical analysis of untreated and treated effluent.

\begin{tabular}{lll}
\hline \multirow{2}{*}{ Elements } & Untreated effluent (collected from DZS) & Treated effluent (using anaerobic bioreactor) \\
\cline { 2 - 3 } & Concentration & Concentration \\
\hline $\mathrm{Zn}$ & $440 \mathrm{ppm}$ & $4.8 \mathrm{ppm}$ \\
$\mathrm{Cu}$ & $1 \mathrm{ppm}$ & $<0.5 \mathrm{ppm}$ \\
$\mathrm{Fe}$ & $160 \mathrm{ppm}$ & $1.8 \mathrm{ppm}$ \\
$\mathrm{As}$ & $1 \mathrm{ppm}$ & $<0.5 \mathrm{ppm}$ \\
$\mathrm{Sb}$ & $<1 \mathrm{ppm}$ & $<0.5 \mathrm{ppm}$ \\
$\mathrm{Mn}$ & $20 \mathrm{ppm}$ & $<0.5 \mathrm{ppm}$ \\
$\mathrm{Cd}$ & $30 \mathrm{ppm}$ & $<0.5 \mathrm{ppm}$ \\
$\mathrm{Ni}$ & $1 \mathrm{ppm}$ & $<0.5 \mathrm{ppm}$ \\
$\mathrm{Pb}$ & $5 \mathrm{ppm}$ & $<0.5 \mathrm{ppm}$ \\
$\mathrm{SO}_{4}{ }^{2-}$ & $8.76 \mathrm{gpl}$ & $0.26 \mathrm{gpl}$ \\
$\mathrm{Acidity}^{-}$ & $4.40 \mathrm{gpl}$ & $\mathrm{pH}=6.8$ \\
\hline
\end{tabular}


Developed bacterial colonies were streak plated and incubated under anaerobic conditions for $48 \mathrm{~h}$. The streak plating was repeated five times to screen the anaerobic SRB. All experiments were conducted in triplicates (45 sets for each step) to isolate the purer SRB culture. The screened colonies were inoculated separately in sealed flasks containing Postgate media and incubated under anaerobic conditions. The maximum grown cultures were taken out (minimum one from each collection site) and TSI (triple sugar iron) test was conducted to confirm the activity of isolates. Selection of SRB was done by ascertaining its efficiency towards sulfate reduction in ten times diluted effluent water of Debari Zinc Smelter. $400 \mathrm{~mL}$ of this diluted effluent was taken in $500 \mathrm{~mL}$ conical flasks and inoculated with respective strains $(10 \% \mathrm{v} / \mathrm{v})$. The flasks were incubated for twenty days and sulfates were analyzed on alternate days. This was done to supplement the conclusion drawn from TSI test for selection of SRB. The batches were named as Ctrl, St 1, St 2, St 3, St 4, St 5 and St 6 for control (inoculated with methanol in place of bacterial strain), roaster, acid plant, ETP (effluent treatment plant), cow dung, oxidation pond ETP and concentrate storage locations.

\subsection{Adaptation of $S R B$}

Selected SRB was developed in Postgate media and was used as inoculum for acclimatization with DZS effluent. DZS effluent was diluted for ten times in a way so that the effluent and nutrient broth (Postgate media) ratio can be maintained as $8: 2(\mathrm{v} / \mathrm{v}) .400 \mathrm{~mL}$ of diluted effluent was taken in to $500 \mathrm{~mL}$ conical flasks and was inoculated $(10 \% \mathrm{v} / \mathrm{v})$ with isolated SRB culture separately. Sterile $\mathrm{N}_{2}$ gas was purged into each conical flask to expel the dissolved oxygen out. The flasks were sealed and incubated for 20 days. This treated effluent was further used as inoculum for diluted DZS effluent and similar procedure was followed for the raw effluent. Flasks were harvested on alternate days and were analyzed for zinc, Iron \& $\mathrm{pH}$. The treatment of effluent without dilution was repeated two times to acclimatize bacteria and after which samples were analyzed daily.

\subsection{Microorganism}

Best-acclimatized culture was named as SRB-CRDL and was maintained in Postgate media under anaerobic conditions. The strain was subcultured at every 20 days.

\subsection{Selection of Carbon Source as Electron Donor}

It was essential to observe the effect of electron donor as well as selection of its cheaper source since; SRB could mediate sulfate reduction to a greater degree when simple carbon and energy sources were available to catalyze the reactions [9]. Nutrient broth (2:8), whey (1:9), ethanol (1:9) and sucrose (1:9) were used as carbon source in effluent water. SRB-CRDL was inoculated separately in $500 \mathrm{~mL}$ sealed conical flasks and flasks were incubated in the similar fashion after purging sterile $\mathrm{N}_{2}$ as discussed earlier. The flasks were harvested for every alternate day and were analyzed for zinc, iron, manganese, lead, cadmium and $\mathrm{pH}$ value. The data collected was used not only for selection of electron donor but also for optimization of days for maximum heavy metals removal and to later design the size of the bioreactors.

\subsection{Semi Batch Type Anaerobic Bioreactors}

Two-stage semi batch type bioreactors were installed to increase the treatment capacity of the system. In first stage, two bioreactors of $10 \mathrm{~L}$ capacity were run for 4 days and $5 \mathrm{~L}$ from each was then transferred to another anaerobic bioreactor of equal capacity for second stage treatment, while first stage bioreactors were again leveled up with fresh effluent. The liquid streams were transferred through peristaltic pumps under anaerobic and sterile conditions. The experimental set up was continued for more than 30 days. In steady state conditions total, $30 \mathrm{~L}$ effluent was treated in 4 days. 


\section{Results and Discussion}

\subsection{Isolation and Selection of SRB}

The results of TSI test for isolated bacterial strains are given in Fig. 1 and Table 2 which shows that the SRB strain isolated from Acid Plant of Debari Zinc Smelter is the best out of the strains isolated from other places. Fig. 2 shows sulfate reduction in ten times diluted effluent water using different isolated cultures. After 20 days of microbiological treatment, experiment confirms that the strain isolated from Acid Plant is the best out of other strains. This supports the result concluded by TSI test. The bacterial strain collected from the Roaster-Acid soil was more adaptable for sulphate ions and hence, it provided the best results in terms of sulphates reduction from the effluent.

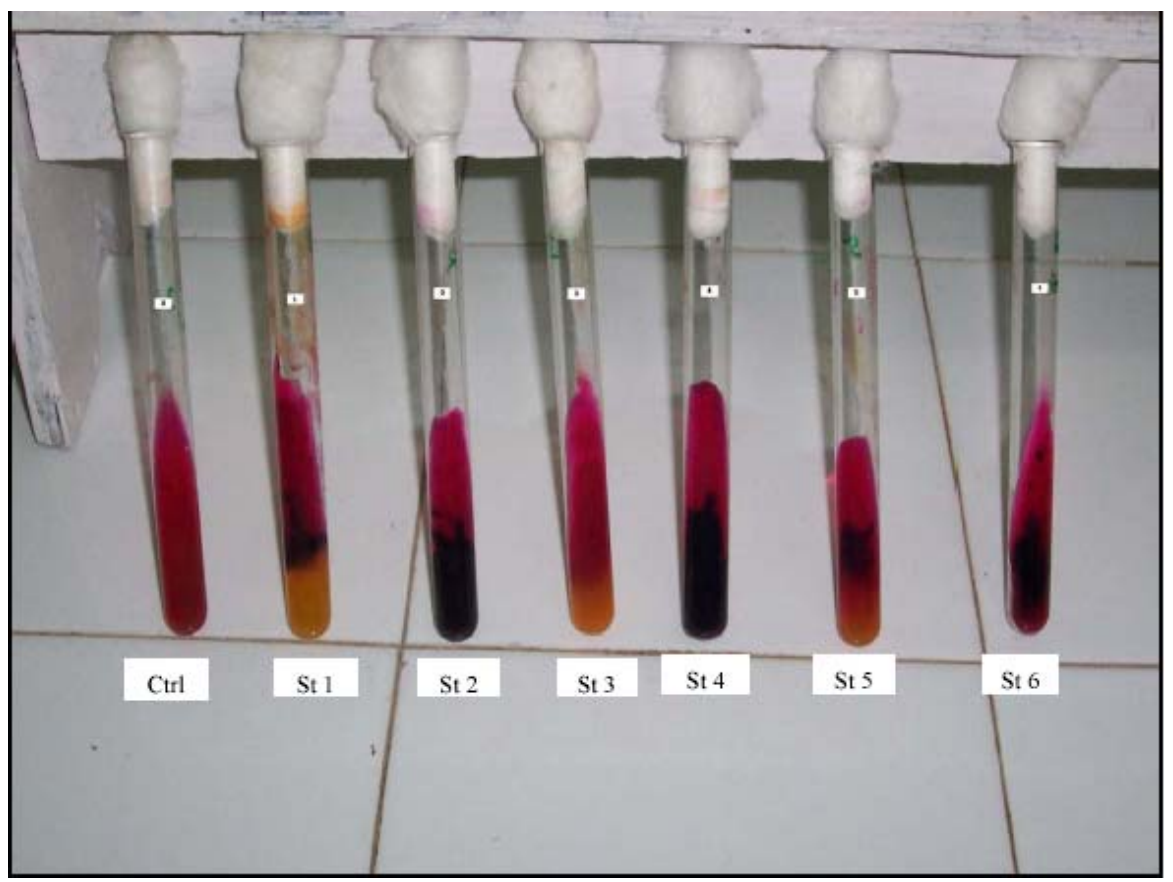

Fig. 1 TSI test.

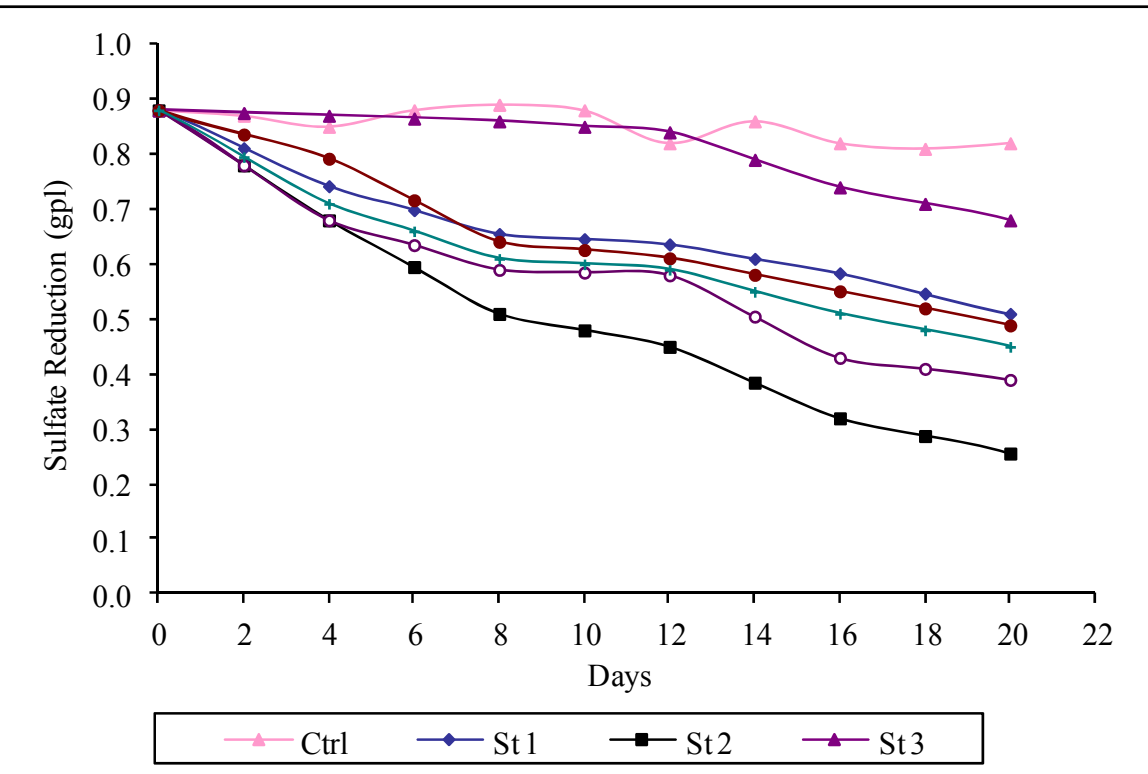

Fig. 2 Reduction in sulfate concentration in ten times diluted DZS effluent w.r.t. different strains. 
Table 2 Analysis of TSI test.

\begin{tabular}{|c|c|c|c|c|c|c|c|c|}
\hline Strain isolate No. & Ctr 1 & St 1 & St 2 & St 3 & St 4 & St 5 & St 6 & \\
\hline Strain collection place & Control & Roaster & $\begin{array}{l}\text { Acid } \\
\text { Plant }\end{array}$ & $\begin{array}{l}\text { ETP (effluent treatment } \\
\text { plant) }\end{array}$ & $\begin{array}{l}\text { Cow } \\
\text { dung }\end{array}$ & $\begin{array}{l}\text { Oxidation } \\
\text { pond ETP }\end{array}$ & $\begin{array}{l}\text { Concentrate } \\
\text { storage }\end{array}$ & Remarks \\
\hline Glucose fermentation & $\mathrm{X}$ & $\sqrt{ } \sqrt{ }$ & $\sqrt{ } \sqrt{ }$ & $\sqrt{ }$ & $\sqrt{ } \sqrt{ }$ & $\sqrt{ }$ & $\sqrt{ }$ & $\begin{array}{l}\text { Red color turns } \\
\text { yellow in butt }\end{array}$ \\
\hline $\begin{array}{l}\text { Lactose/sucrose } \\
\text { fermentation }\end{array}$ & $\mathrm{X}$ & $\mathrm{X}$ & $\sqrt{ }$ & $\sqrt{ }$ & $X$ & $\sqrt{ }$ & $\mathrm{X}$ & $\begin{array}{l}\text { Red color turns } \\
\text { yellow on slant }\end{array}$ \\
\hline $\mathrm{H}_{2} \mathrm{~S}$ gas production & $\mathrm{X}$ & $\sqrt{ }$ & $\sqrt{ } \sqrt{ }$ & $\mathrm{X}$ & $\sqrt{ } \sqrt{ }$ & $\sqrt{ }$ & $\sqrt{ }$ & $\begin{array}{l}\text { Blackish color in } \\
\text { butt after yellow }\end{array}$ \\
\hline Gas production $\left(\mathrm{H}_{2} / \mathrm{CO}_{2}\right)$ & $\mathrm{X}$ & $\mathrm{X}$ & $\sqrt{ }$ & $\mathrm{X}$ & $\mathrm{X}$ & $\mathrm{X}$ & $\mathrm{X}$ & $\begin{array}{l}\text { Creaks or shifting } \\
\text { of slant }\end{array}$ \\
\hline
\end{tabular}

\subsection{Adaptation of $S R B$}

Fig. 3 represents the adaptation graph of the selected SRB. The adaptation was started with 10 times dilution for 20 days while second peak in the graph is for 5 times dilution batch and was run for another 20 days, which is followed by adaptation of SRB without any dilution of effluent water. The similar experiment is repeated for two more times. After 92 days of adaptation experiments, the bacteria were adapted to reduce heavy metals concentration in acidic effluent water to permissible limits as per environment norms. The adapted bacteria are capable of reducing heavy metals with major constituent of zinc $500 \mathrm{ppm}$ concentration to less than $5 \mathrm{ppm}$ and $\mathrm{pH}$ of less than 1.0 to almost neural $\mathrm{pH}$ within 12 days of biological treatment. Only $\mathrm{Zn}$ and $\mathrm{Fe}$ were considered in establishing the parameters since these are the major constituents of the effluent water.

\subsection{Selection of Carbon Source as Electron Donor}

It was required to expedite the heavy metal removal to handle larger effluent volume. SRB could mediate sulfate reduction to a greater degree when simple carbon and energy sources were available to catalyze the reactions [9]. Table 3 represents reduction in heavy metals concentration (zinc, iron, cadmium,

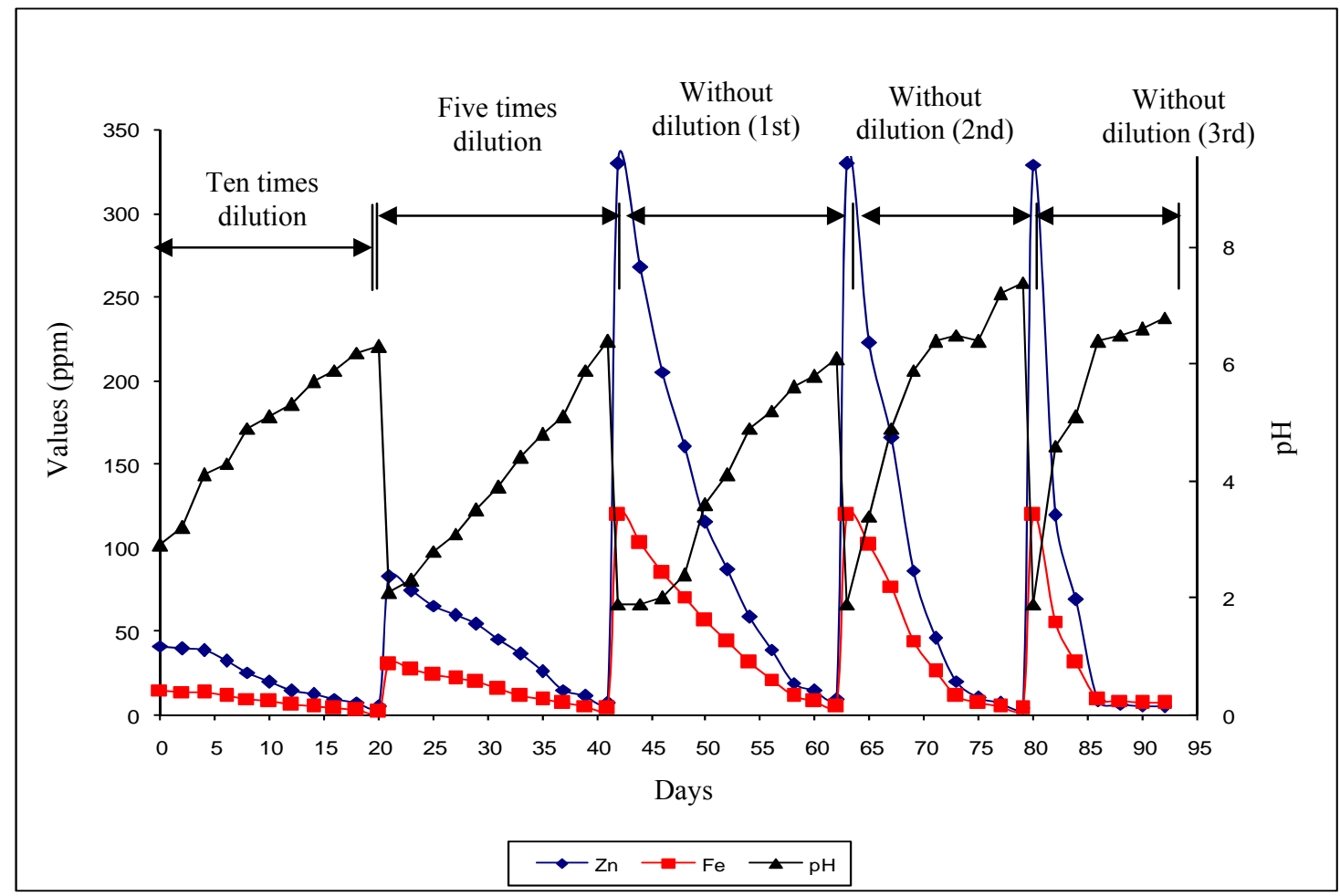

Fig. 3 Adaptation of SRB isolate. 
Table 3 Effect of electron donors on percentage reduction of heavy metals and sulfate concentration.

\begin{tabular}{|c|c|c|c|c|c|c|c|c|}
\hline \multirow[b]{2}{*}{ Days } & \multicolumn{4}{|c|}{ Zinc } & \multicolumn{4}{|c|}{ Iron } \\
\hline & $\begin{array}{l}\text { Nutrient broth } \\
(2: 8)\end{array}$ & $\begin{array}{l}\text { Whey } \\
(1: 9)\end{array}$ & $\begin{array}{l}\text { Ethanol } \\
(1: 9)\end{array}$ & $\begin{array}{l}\text { Sucrose } \\
(1: 9)\end{array}$ & $\begin{array}{l}\text { Nutrient broth } \\
(2: 8)\end{array}$ & $\begin{array}{l}\text { Whey } \\
(1: 9)\end{array}$ & Ethanol (1:9) & $\begin{array}{l}\text { Sucrose } \\
(1: 9)\end{array}$ \\
\hline 0 & 0 & 0 & 0 & 0 & 0 & 0 & 0 & 0 \\
\hline 2 & 43.06 & 49.16 & 10.44 & 15.20 & 36.57 & 50.87 & 26.29 & 29.89 \\
\hline 4 & 66.79 & 74.19 & 28.35 & 27.88 & 65.64 & 68.53 & 41.06 & 40.16 \\
\hline 6 & 79.14 & 88.07 & 51.65 & 57.33 & 83.74 & 86.27 & 64.64 & 66.49 \\
\hline 8 & 91.89 & 97.40 & 62.66 & 76.11 & 90.24 & 95.60 & 73.71 & 81.53 \\
\hline 10 & 97.15 & 98.77 & 71.65 & 86.28 & 94.08 & 97.20 & 86.09 & 88.52 \\
\hline 12 & 98.54 & 99.30 & 87.23 & 93.44 & 94.25 & 97.53 & 87.48 & 92.68 \\
\hline \multirow[b]{2}{*}{ Days } & \multicolumn{4}{|c|}{ Cadmium } & \multicolumn{4}{|c|}{ Manganese } \\
\hline & $\begin{array}{l}\text { Nutrient broth } \\
(2: 8)\end{array}$ & $\begin{array}{l}\text { Whey } \\
(1: 9)\end{array}$ & $\begin{array}{l}\text { Ethanol } \\
(1: 9)\end{array}$ & $\begin{array}{l}\text { Sucrose } \\
(1: 9)\end{array}$ & $\begin{array}{l}\text { Nutrient broth } \\
(2: 8)\end{array}$ & $\begin{array}{l}\text { Whey } \\
(1: 9)\end{array}$ & $\begin{array}{l}\text { Ethanol } \\
(1: 9)\end{array}$ & $\begin{array}{l}\text { Sucrose } \\
(1: 9)\end{array}$ \\
\hline 0 & 0 & 0 & 0 & 0 & 0 & 0 & 0 & 0 \\
\hline 2 & 33.19 & 35.89 & 30.30 & 32.43 & 38.81 & 43.90 & 34.20 & 40.99 \\
\hline 4 & 79.14 & 84.18 & 72.43 & 81.13 & 87.11 & 91.90 & 84.09 & 91.32 \\
\hline 6 & 98.54 & 99.88 & 97.99 & 99.98 & 98.75 & 99.87 & 98.32 & 99.19 \\
\hline 8 & 100.0 & 100.0 & 100.0 & 100.0 & 100.0 & 100.0 & 100.0 & 100.0 \\
\hline 10 & 100.0 & 100.0 & 100.0 & 100.0 & 100.0 & 100.0 & 100.0 & 100.0 \\
\hline 12 & 100.0 & 100.0 & 100.0 & 100.0 & 100.0 & 100.0 & 100.0 & 100.0 \\
\hline \multirow{2}{*}{ Days } & \multicolumn{8}{|c|}{ Sulfate } \\
\hline & \multicolumn{2}{|c|}{ Nutrient broth $(2: 8)$} & \multicolumn{2}{|c|}{ Whey (1:9) } & \multicolumn{2}{|l|}{ Ethanol (1:9) } & \multicolumn{2}{|l|}{ Sucrose (1:9) } \\
\hline 0 & \multicolumn{2}{|c|}{0} & \multicolumn{2}{|l|}{0} & \multicolumn{2}{|l|}{0} & \multicolumn{2}{|l|}{0} \\
\hline 2 & \multicolumn{2}{|l|}{17.78} & \multicolumn{2}{|l|}{21.20} & \multicolumn{2}{|l|}{15.09} & \multicolumn{2}{|l|}{18.78} \\
\hline 4 & \multicolumn{2}{|l|}{31.32} & \multicolumn{2}{|l|}{39.98} & \multicolumn{2}{|l|}{30.39} & \multicolumn{2}{|l|}{37.18} \\
\hline 6 & \multicolumn{2}{|l|}{46.63} & \multicolumn{2}{|l|}{58.71} & \multicolumn{2}{|l|}{46.90} & \multicolumn{2}{|l|}{51.18} \\
\hline 8 & \multicolumn{2}{|l|}{61.29} & \multicolumn{2}{|l|}{78.88} & \multicolumn{2}{|l|}{58.09} & 68.81 & \\
\hline 10 & 70.37 & & 89.13 & & 70.87 & & 79.72 & \\
\hline 12 & 90.56 & & 97.12 & & 90.18 & & 93.87 & \\
\hline
\end{tabular}

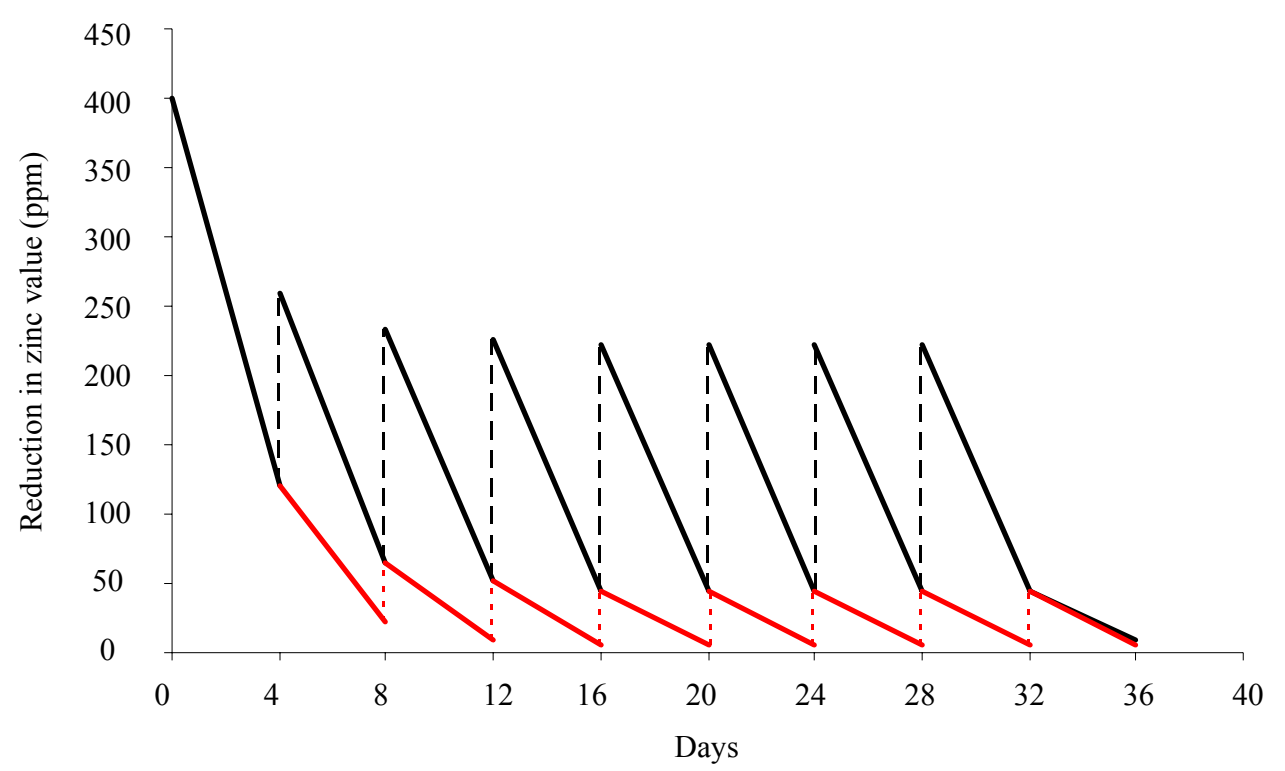

Fig. 4 Reduction in zinc concentration in two-stage anaerobic bioreactor using whey (1:9). 


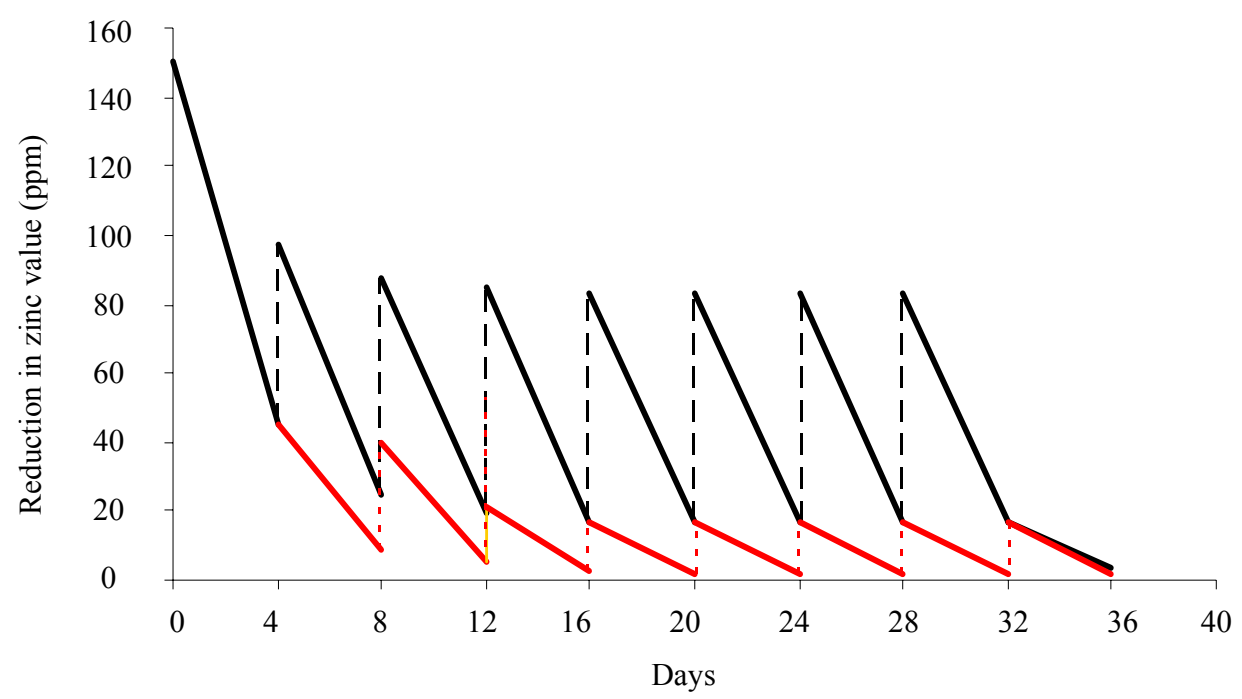

Fig. 5 Reduction in iron concentration in two-stage anaerobic bioreactor using whey (1:9).

and manganese) and sulfates in presence of nutrient broth (2:8), whey (1:9), ethanol (1:9) and sucrose (1:9) respectively. After 12 days of biological treatment, $99.30 \%$ and $97.53 \%$ reduction in zinc and iron, respectively was observed using whey as electron donor while for nutrient broth, ethanol and sucrose zinc reduction is $98.54 \%, 87.23 \%$ and $93.44 \%$, respectively and for iron it is $94.25 \%, 87.48 \%$ and $92.68 \%$, respectively. Sulfate reduction in all the electron donor sources is almost $90 \%$ other than whey (97.12\%). After 6 days, treatment in all the cases, cadmium and manganese have reached to a level in traces. Whey was selected as best source for electron donor considering the reduction in heavy metal concentration and its cost.

\subsection{Two-Stage Anaerobic Bioreactors}

Figs. 4 and 5 show the treatment pattern of two stage anaerobic bioreactors for zinc and iron reduction. Upper solid lines represent first stage reactor and lower solid lines are for second stage reactor treatment. In both first stage anaerobic reactors, after 4 days of treatment period the zinc and iron concentration reduced up to $124.4 \mathrm{ppm}$ and $45.0 \mathrm{ppm}$, respectively. $5 \mathrm{~L}$ from total $10 \mathrm{~L}$ was transferred to second stage treatment process, where $\mathrm{Zn \& Fe}$ reduced to $23.6 \mathrm{ppm}$ and $8.5 \mathrm{ppm}$, respectively, while the first stage reactor which has been leveled up with fresh effluent reduced has reduced these metals to $67.4 \mathrm{ppm}$ and $24.4 \mathrm{ppm}$, respectively. This is again transferred to second stage reactor and reduced to $9.3 \mathrm{ppm}$ and $5.6 \mathrm{ppm}$. The similar process is being continued for 36 days and under steady state conditions the zinc and iron concentration in treated effluent was $4.9 \mathrm{ppm}$ and 1.8 ppm with treatment capacity of $30 \mathrm{~L}$ effluent in 4 days. The steady state condition was achieved after 20 days of treatment period.

\section{Conclusions and Recommendations}

Sulfate reducing bacteria isolated from Acid Plant of Debari Zinc Smelter, Hindustan Zinc Ltd., Udaipur, India was found the best isolate.

It was acclimatized for high heavy metals concentration $($ zinc $\approx 500 \mathrm{ppm}$, iron $\approx 160 \mathrm{ppm}$ ) under highly acidic solution $(\mathrm{pH}<1.0)$.

Whey was found as the best electron donor in the effluent treatment.

Two-stage anaerobic bioreactor with treatment capacity of $30 \mathrm{~L}$ effluent has successfully reduced heavy metals as metal sulfides and attained almost neutral $\mathrm{pH}$ within short duration of 4 days. The pilot runs on the process confirm that it may be commercialized for treatment of effluents of zinc plants. 


\section{Acknowledgements}

Authors would like to thank management of Hindustan Zinc Ltd. for granting permission to publish this paper. Technical guidance from Mr. Kamath and Mr. Mohanty is also acknowledged.

\section{References}

[1] Lens, P. N. L.; Visser, A.; Jansen, A. J. H.; Hulshoff, P. L. W.; Lettinga, G. Crit. Rev. Environ. Sci. Technol. 1998, 28, 41-88.

[2] Silva, A. J.; Varesche, M. B.; Foresti, E.; Zaiat, M. Process Biochemistry 2001, 37, 927-935.

[3] Jong, T.; Parry, D. L. Water Research 2003, 37, 3379-3389.

[4] Christensen, B., Laake M., Lien T. Water Research 1996, 30, 1617-1624.

[5] Tsukamoto, T. K.; Killion, H. A.; Miller, G. C. Water
Research 2004, 38, 1405-1418.

[6] Vegt, A. L. D.; Dijkman, H.; Busiman, C. J. N. TMS Annual Meeting, San Antonio, Texas, 1998.

[7] Lowrie, D.; Hobson, J.; Stuckey, D. C. Water Science and Technology 2002, 45, 287-292.

[8] Barton, L. L.; Tomei, F. Sulfate Reducing Bacteria; Plenum Press: New York, 1995.

[9] Drury, J. W. Water Environment Research 1999, 71, 1244-1250.

[10] Widdel, F. Biology of Anaerobic Microorganisms; Zehnder, A. J. B., Ed.; Wiley: New York, 1988.

[11] Dinwoodie, J. M. Wood: Nature's Cellular. Polymeric Fibre-Composite; The Institute of Metals, London, 1989.

[12] Stafford, D. A.; Hawkes, D. L.; Horton, R. Methane Production from Waste Organic Matter; CRC Press: Boca Raton, F.L., 1980.

[13] Postgate, J. R. The Sulfate Reducing Bacteria; Cambridge University Press: Cambridge, 1984. 